PRODUCTION

ENGINEERING

ARCHIVES
2014, Vol. 3, No 2, pp 26-30

ISSN 2353-5156 (print version)

ISSN 2353-7779 (online version)

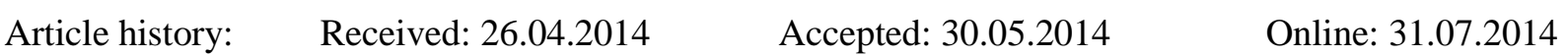

\title{
Controlling of the logistic processes
}

\author{
Robert Ulewicz $^{1}$, Alan Vaško ${ }^{2}$, Dorota-Klimecka-Tatar ${ }^{3}$ \\ ${ }^{1}$ Czestochowa University of Technology, Faculty of Management, Institute of Production Engineering. e-mail, ulewicz@ zim.pcz.pl \\ ${ }^{2}$ University of Žilina, Faculty of Mechanical Engineering, Department of Materials Engineering, e-mail: alan.vasko@ fstroj.uniza.sk \\ ${ }^{3}$ Czestochowa University of Technology, Faculty of Management, Institute of Production Engineering. e-mail, klimt@ wip.pcz.pl
}

\begin{abstract}
The paper presents analysis of the controlling application in logistic processes in the foundry of the cast iron. Controlling of quality was introduced in order to raise efficiency of the foundry of the cast iron management. A comparative method was applied to examinations. Two spheres were compared to managing of the organization: managing the quality by the sphere with the zone of management with finances. The purpose of this action is finding common features when supervising tasks in both these zones.
\end{abstract}

Key words - controlling, logistic, quality, cast iron

\section{Introduction}

Many changes have occurred in the logistics of companies in recent years. Its growing importance results from challenges of the market that companies have to face, such as: higher requirements regarding the time of supplies, supplies themselves, the bigger variety of products and ensuring the quality of the product. These tendencies led to the increase in coordination, and the same to the increase in indirect expenses. With effect of these phenomenas a need to appoint logistic controlling has arisen at project tasks and control through preparing necessary information. Within the confines of co-ordinating of the company exists a purpose of logistic controlling in finding the potential improvement in each links of the logistic chain (GRABARA J.2012, et al., BORKOWSKI S., INGALDI M. 2013, JELONEK D. 2001.). It may mean desired supply of customers, by quick transfer of information from customers in the information chain, relatively timely material supply at minimal good stor- age, short production cycles and agreed capacities. Forming and communication of logistic purposes are posing the assumption to arise logistic consciousness in the company that in practice, will make every worker regard logistics as the factor of the potential cost cutting and the potential increase in sale. It is necessary in logistics to mean controlling as the method of management that is directed to the realization of planning processes, the assurance of the quality, control and information within the confines of logistic areas inside the company along with tying with the environment. For most companies quality deliveries present the key area for the production process. Quality, in the presented case, means rhythmicity and quantity and technical parameters accordance to the orders. Whereas sales present the area deciding about the market success of the company, purchases and sales present two extreme company activities The first one determines the beginning of production in a strictly determined term under condition of proper input material obtaining. The second one enables organised cooperation with the receivers. In both cases efficient 
logistics processes controlling, eliminating breaks, unpunctuality of order realisation etc.,should be assured. Stock and capital engaged optimalization usually brings company running cost reduction and increasing of its fluctuation, especially when the product being produced presents an industrial product, eg. cast form when, significant part of entire cost (about 50\%) present cost connected with the material (CHLUSKA J. 2006, BORKOWSKI S., ROSAK-SZYROCKA J., SZKLARZYK P. 2011, KOŚCIELNIAK H., NOWAKOWSKA-GRUNT J. 2009).

\section{Logistics processes controlling}

Controlling presents the only logical and compact answer to processes taken place in the company and its environment. Materials flow as well as production and management processes play an important role. The controlling system compares the norm determined by the schedule and the plan with the real state, taking under consideration the economic dimension of existing derivations. Comparison assessment of the real state with an assumed one can bring two results: the first - when the real state meets the norm limitations (no repair activities) and the second - when the real state doesn't meet the norm limitations (repair activities should be taken). Due to information obtained the controlling department make an analysis showing how much the production state depends on stock, human resources, development researches, available technologies and the market situation. Figure 1 shows controlling on the background of key areas of the company which is being under analysis.

Though it was possible to speak about controlling universal, it is first necessary to present four basic procedures that, irrespective of controlling will have to be conducted. To these procedures range from:

\section{- procedure „0" - construction of the controlling} base.

This procedure contains both the reporting part and steering. In the first, the market plan has echnical-organizational gagers occurring, as well as financial reporting tied with basic positions of the total effect, flows of the capital and the income statement tied to basic positions of the total effect, flows of the capital and the income statement gagers.

\section{- procedure „1" - security organizational- informative of controlling system in organiza- tional structures of the company.}

This procedure refers to determining the range of the responsibility for creation of the base of each controlling services, leading records and actual monitoring of size as well as calculating and analysing deviations of sizes of gagers:

o indicators of the market plan technicalorganizational,

$\circ$ indicators of financial reporting,

$\circ$ steering indicators.

- procedure „2" - specification of the level of permitted deviations utilized for indicators in the controlling system.

This procedure refers to the specification legal deviations of base indicators. It shows the variant approach to creating the method of legal frontier size.

\section{- procedure ,3 - correcting working.}

This procedure refers to taking the decision of accepted size of gagers. In the case of the measured deviation size from base, it is necessary in the legal interval to determine the indicator at least a possible reason for suchphenomena (MARCINIAK S. 2001).

During designing controlling procedures it is possible for the logistics system to utilize occurring gagers:

- Level of the customer service:

- state of material provisions,

- state of provisions of production in progress,

- state of provisions of final goods,

- state of the physical flow of materials,

- state of computer processes;

- Market position:

- market share in basic assortments,

- market share in all assortments,

o changes in the market share in general,

- valuable participation of own logistic processes in demand for logistics in general;

- Remuneration:

○ level of expenses of logistics,

o participation of expenses of logistics in expenses of producing,

- level of producing expenses,

- level of sale expenses,

$\circ$ income in general, 
○ remuneration of logistics,

$\circ$ remuneration of producing

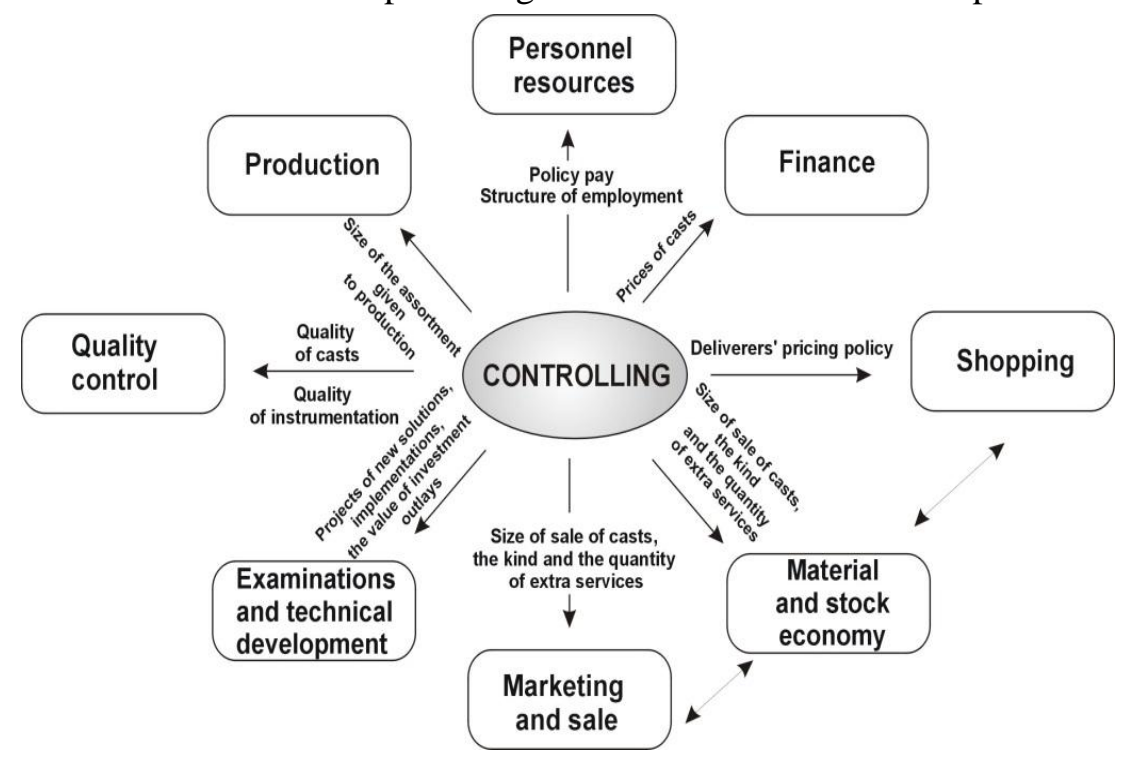

and expectations of customers. Properly identified aspects outlined the aims of the organization as well as processes connected with them. Usually there are separate aims for quality sphere, environment, safety of work and finances which simplify the delegation of responsibility and controlling. The combining of aims in all spheres of management is not recommended. In the planning of assignments of quality for the whole organization proxy defines main priorities thus: periodical reviews, audits, correcting assignments. The final stage of activities present an annual report including breakdowns, appeared threats. The report should contain analysis of management efficiency as well as management quality improvement

Fig. 1. Main relations of controlling system with impact put on purchases and sales logistics processes.

Source: own study.

\section{Controlling of the quality}

The methodology described in the paper (ULEWICZ R., et al. 2002) was used in the investigations to assemble data. The following techniques of document investigation were applied, interviewed and participating observation was undertaken. Analysis of the following documents: processes, complimentary cards of orders, reports from audits, plans of quality of proxies, reports about state of qualities, protocols from radium sessions of qualities and sessions of supervisory advice as well as financial reporting were executed.

The following activity plan was established:

- Defining of aspects and aims,

- Planning of realization of activities,

- Realization of activities,

- Control of activities realization,

- Analysis of final results and recapitulation.

In the first stage of work the aims of the organization were defined from the point of view of quality, environment, safety of work and finances. Uncertain places were established in the realization of enterprise with regard to norms, regulations of rights activity. A similar plan of conduct concerns the sphere of management finances as well. In the sphere of quality as well as finances, two councils act - the council of quality supervises fulfilment of universal aims, the supervisory council supervises fulfilment of the objectives of results-oriented. A great similarity between controlling running in spheres of quality and finance management, therefore fast integration of these spheres is possible. Comparison of financial sphere and qualities was introduced in Table 1.

Table 1. Comparison of financial sphere and qualities

\begin{tabular}{|c|c|c|c|}
\hline Element & $\begin{array}{c}\text { Defining of } \\
\text { element }\end{array}$ & $\begin{array}{c}\text { Quality } \\
\text { management } \\
\text { zone }\end{array}$ & $\begin{array}{c}\text { Finance } \\
\text { management } \\
\text { zone }\end{array}$ \\
\hline \multirow{3}{*}{$\begin{array}{c}\text { Responsibility } \\
\text { for controlling } \\
\text { procces }\end{array}$} & Initiator & $\begin{array}{c}\text { Management } \\
\text { proxy of } \\
\text { quality system }\end{array}$ & $\begin{array}{l}\text { Finance } \\
\text { controller }\end{array}$ \\
\hline & $\begin{array}{c}\text { References } \\
\text { center }\end{array}$ & Quality board & $\begin{array}{c}\text { Chairmen } \\
\text { board }\end{array}$ \\
\hline & Recipient & $\begin{array}{c}\text { Externeal } \\
\text { auditor }\end{array}$ & Accountant \\
\hline Tools & & $\begin{array}{c}\text { Audit, } \\
\text { inspection, } \\
\text { periodical } \\
\text { survey. }\end{array}$ & $\begin{array}{c}\text { Stock-taking, } \\
\text { inventory, } \\
\text { servey }\end{array}$ \\
\hline \multirow{4}{*}{$\begin{array}{l}\text { Documents } \\
\text { connected with } \\
\text { controlling } \\
\text { procces }\end{array}$} & Initiating & Quality plan & Finance plan \\
\hline & $\begin{array}{l}\text { Periodical } \\
\text { survey }\end{array}$ & $\begin{array}{l}\text { Periodical } \\
\text { report }\end{array}$ & Finance report \\
\hline & Finalizing & $\begin{array}{c}\text { Quality state } \\
\text { report }\end{array}$ & $\begin{array}{c}\text { Company } \\
\text { balance }\end{array}$ \\
\hline & Improving & \multicolumn{2}{|c|}{ Business plan } \\
\hline
\end{tabular}

Source: own study. 
The gaining and analyzing of all kinds of information for the present activity is fundamental for the controlling unit. Information flow between particular company departments has an immense influence on the manner of production steering. Information flow in organizations influences, among other things, stock conditions and its connection with current production and purchase. Controlling thanks to extensive information analyzes how much depends on the state of production from stocks, from human resources, research and development, and technology available on the market situation. The co-ordination level between marketing department activity, the production department and the development department appeared to be very important. The controlling unit plays the role of co-ordinator here. Controlling plays a significant role in quality assurance and it optimizes the product steering process. Functioning of the company in the trial setup with applying controlling requires insertions of the iron information discipline. Persons participating in these processes should report up-to-date information about the mark of the realization of tasks. This is so that managers of processes possessed current information about rising pertubations (BORKOWSKI S. 2004, BOKUVKa O. et al. 2001, STASIAK -BETLEJEWSKA R., BORKOWSKI S. 2009).
As an example, Figure 2 demonstrates that data is being recorded within the confines of led action which pose the necessary, basic information resource e perhaps for efficiently controlling functioning.

\section{Summary}

Properly implemented controlling the quality of logistics and quality in the company contributes to the sustainability of its existence in two ways. On the one hand it is assisting and making coordination of logistic processes and management possible with quality, laying the speciallstress on planning and the control of the quality of chains of supplies, and is interacting through positive impact on produced production for the increase in competitiveness of products and the increase in income of the company. On the other hand, controlling processes in their operations forces to continually drive costs incurred in enterprise quality and the impact on them by seeking opportunities to reduce their bills. Therefore also controlling, through one's direct influence on expenses and intermediate for income, and causing the company to increase remuneration. Implementation of enterprise process management system allows you to organize the company in terms of the processes. The controlling system is helping with it

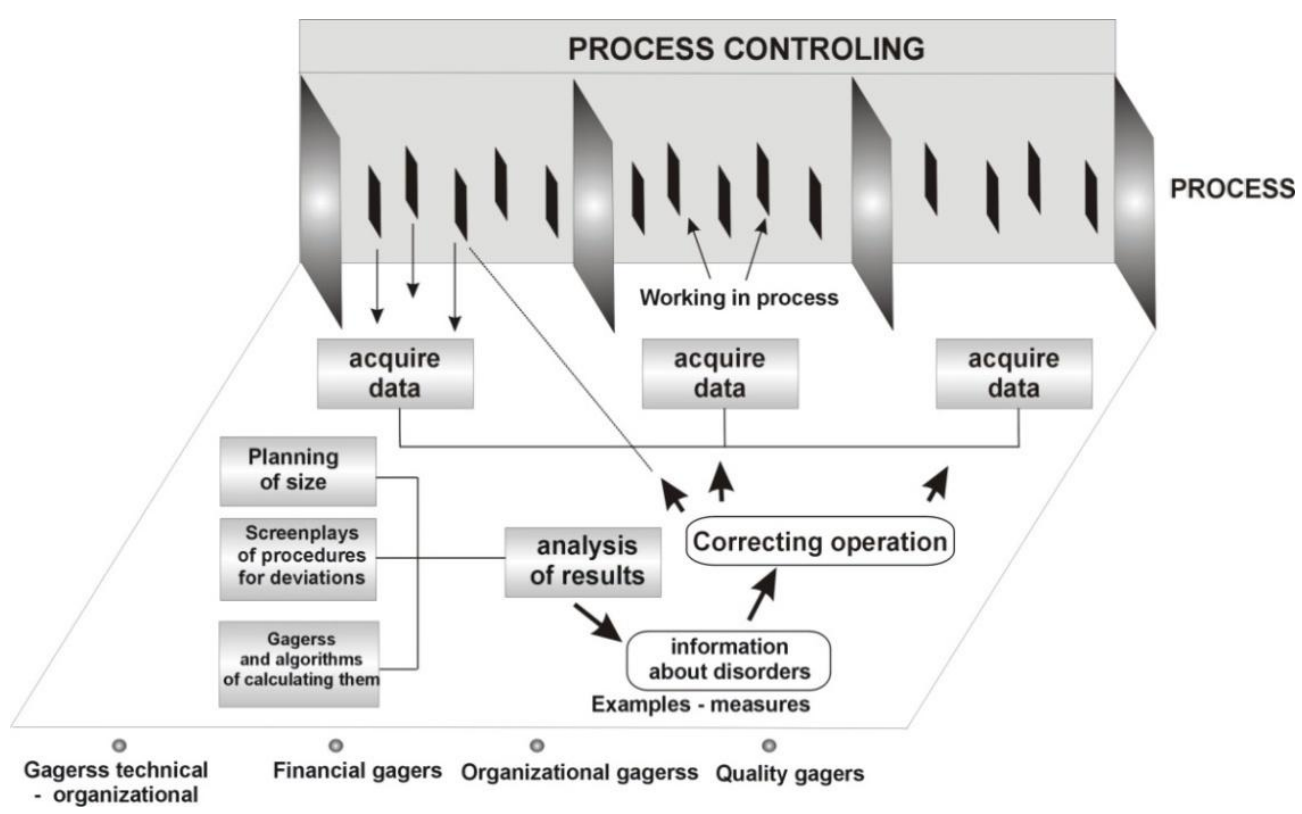
fulfilling the part of the steering element which was also subordinated to processes. The process team in the company have to use simple tools, adapted to processes realized by them in the best possible manner in order to ensure conformity in this way on internal „markets” companies. Identifying centres of responsibility in the process of production of casts cause the final goods to be able to remain delivered at the right time, to the right place and perhaps produced at a suitably low expense. The controlling system has to adapt Fig. 2. Process controlling Source: own study. itself to changing internal customers and conditions of executed operations. Controlling of processes is sup- 
posed to help at total shaping, the control and at the estimation of processes. It is working to find suitable determining factors of the realization of processes and grasping their indicators suitable in form or measurement.

\section{Literature}

7. Bokuvka O., Palcek P., Chalupova M., Ulewicz R. 2001: Kvalita konstrucnych suczasti a zaradieni, Zarządzanie rozwojem organizacji, Jakość procesów i produktów, Wyd. WSZiM Sosnowiec, Sosnowiec.

8. BORKOWSKI, S. 2004. Mierzenie poziomu jakości, Wyd. WSZiM w Sosnowcu, Sosnowiec.

9. Borkowski S., Rosak-SzYrocka J., SzKLARZYK P. 2011. Control of the Steel Construction of Halls. Chapter 6., Toyotarity. Control in Organizations. Monography. Editing and Scientific Elaboration STANISŁAW Borkowski, AgnieszKa CZAJKOwska. Publish.Yurii V. Makovetsky, Dnipropetrovsk s.87-104.

10. BORKOWSKI S., INGALDI M. 2013. Toyotarity. Evoluation and Processes'/Products' Improvement. Aeternitas Publishing House, Alba Iulia. Romania.

11. BorUt J., ROSAK-SZYROCKA J. 2014. Quality of investments in logistic, Production Engineriing Archves, Vol 2, No.1.

12. CHLUSKA J. 2006. Kosztowe aspekty zarzadzania, Wydawnictwo Politechniki Częstochowskiej, Częstchowa.

13. Grabara J., MAN M., Kot S. 2012, Costs Incurred by Designing and Implementing the Logistical Projects in the Activity of Companies. CECOL 2012. III Central European Conference on Logistics. Trnava, Slovak Republic.

14. JELONEK D. 2001. Efektywność komputerowo wspomaganego monitoringu otoczenia przedsiębiorstwa, Efektywność zastosowań systemów informatycznych. T.II.Pod red. J. GRABARY, J. NOWAKA.WarszawaSzczyrk s.39-44.

15. KościelniaK H., NowaKowsKa-Grunt J. 2009. Zastosowanie wskaźnika syntetycznego $w$ monitoringu finansowym przedsiębiorstw. Zeszyty Naukowe Uniwersytetu Szczecińskiego nr 577 Finanse, Rynki Finansowe, Ubezpieczenia $\mathrm{nr} 23$.

16. MARCINIAK S. 2001. Controlling, filozofia, projektowanie, Difin, Warszawa.

17. Stasiak -Betlejewska R., BORKOWski S. 2009. Controlling $w$ odniesieniu do systemu produkcyjnego. Cele $i$ uwarunkowania funkcjonowania współczesnych przedsiębiorstw. Redakcja naukukowa JANUSZ DWORAK, TADEUSZ FALENCIKOWSKI. s.77-90

18. UlEWICZ R., Novy F., KoPAS P. 2002. Quality control of production metalurgical rolls from nodular cast iron, Material Engineering, Vol.10 nr 3/2002. 